\title{
In vivo and in vitro methods of measuring nutritive value of leaf-protein preparations
}

\author{
By R. A. BUCHANAN * \\ Rothamsted Experimental Station, Harpenden, Herts. \\ (Received I November I968-Accepted I7 March 1969)
}

\begin{abstract}
I. Several in vitro methods were compared with in vivo methods for estimating the nutritive value of leaf-protein concentrates (LPC), using a freeze-dried preparation from wheat (A) fresh, (B) after heating moist, (C) after heating moist and then extraction with chloroform, and (D) after extraction with an acidified solvent.

2. The treatments had little effect on the biological value (BV) of the samples for rats.

3. Heating moist decreased true digestibility (TD), net protein utilization (NPU) and protein efficiency ratio (PER), but the original values were almost restored by lipid extraction. Acidified solvent extraction decreased TD, NPU and PER of LPC perhaps by making it brittle and difficult to wet.

4. Papain solubility and TD were well correlated. Pepsin-pancreatin solubility and TD were less well correlated.

5. Microbiological estimations of available amino acids, involving predigestion with pepsin, correlated poorly with TD determinations.

6. Unsaturated fatty acids, particularly linolenic, formed complexes during heating of LPC. The effect of this on enzyme solubilization procedures and on digestion in vivo is discussed.

7. Some comparisons are made between the effect of heat and of extraction with solvents on LPC and on fish meal.
\end{abstract}

The widely varying estimates of the nutritive value of leaf-protein concentrates (LPC) made outside Rothamsted and even those made at Rothamsted up to I957, can be attributed largely to improper processing, especially to poor washing and overheating during drying.

Many studies have shown that the amino acid distribution in LPC usually compares favourably with the 1957 FAO provisional amino acid pattern (Ellinger, 1954; Pleshkov \& Fowden I959; Gerloff, Lima \& Stahmann, 1965; Valli Devi, Rao \& Vijayaraghavan, 1965). The nutritive value when fed to infants (Waterlow, 1962), pigs (Duckworth, Hepburn \& Woodham, I96I), chicks (Duckworth \& Woodham, I96r) and rats (Henry, I959) was generally good. But Henry \& Ford (I965) found that its biological value (BV), true digestibility (TD) and net protein utilization (NPU) varied with the species and age of the leaves and with the method of drying.

In efforts to simplify methods of assessing nutritive value, several enzyme solubilization procedures have been tested. One object of this work was to compare the effectiveness of several of these methods in detecting changes in nutritive value during processing of LPC. The LPC was treated in ways designed to give widely differing nutritive values after treatment.

The papain solubilization procedure of Buchanan \& Byers (1969) was the only in vitro method to give a satisfactory correlation with in vivo results for rats.

Reactions taking place during heating and extraction with lipid solvents were studied. It is shown that solvent extraction may be used to improve the digestibility of LPC.

* Present address: Division of Dairy Research, C.S.I.R.O., Highett, Victoria, 3190, Australia. 


\section{EXPERIMENTAL}

\section{Preparation of samples}

Several leaf-protein samples were prepared (Table 1).

A. Wheat leaf protein extracted according to the method of Morrison \& Pirie (I96r) was freeze-dried and stored for 16 months at $-10^{\circ}$ then ground in a mechanical pestle and mortar to pass a 28 -mesh sieve with 0.030 in $^{2}$ holes.

B. One part of water was added to I 15 parts of the same material in a glass flask. This was then sealed by fusing the neck, kept in an oven at $105^{\circ}$ for $5 \mathrm{~h}$, cooled and opened.

C. Part of the heated sample (B) was extracted with chloroform at room temperature, filtered and dried in a vacuum oven at $36^{\circ}$ for $24 \mathrm{~h}$.

D. Part of the original material (A) was extracted at room temperature with 2: $1(\mathrm{v} / \mathrm{v})$ chloroform:methanol containing $\mathrm{I} \% \mathrm{HCl}$, filtered and dried in a vacuum oven at $36^{\circ}$ for $24 \mathrm{~h}$. The resultant brittle horny protein product was ground to pass a $0.7 \mathrm{~mm}$ circular mesh screen.

Also, a $3.75 \mathrm{~g}$ sample of $\mathrm{D}$ was ground with a pestle and mortar, dispersed in $30 \mathrm{ml}$ of water and allowed to settle for $15 \mathrm{~min}$, decanted, resuspended in $10 \mathrm{ml}$ of water and allowed to stand for $\mathrm{I} \mathrm{h}(\mathrm{pH} 6 \cdot 4)$. The upper layer of water and very fine suspended protein was then decanted. Both the suspended material and the sediment were centrifuged at $1000 \mathrm{~g}$ for $\mathrm{I}$ o $\mathrm{min}$, and the supernatant fluid was discarded; each fraction was resuspended in citrate-phosphate buffer $(\mathrm{pH} \mathrm{6.6)}$ and allowed to stand overnight. These suspensions were used to determine the in vitro solubility by papain after soaking.

E. Part of the original material (A) was extracted at room temperature in the same way as $\mathrm{D}$ with 2:1 chloroform:methanol containing $\mathrm{r} \% \mathrm{HCl}$, then washed in several large volumes of distilled water, soaked for $3 \mathrm{~h}$ in a large volume of water adjusted to $\mathrm{pH} 6.0$ with $\mathrm{NaOH}$, filtered and dried in a vacuum oven at $39^{\circ}$ for $24 \mathrm{~h}$. The resultant brittle product was ground to pass a $60-$ mesh screen.

\section{Moisture determination}

\section{Analytical methods}

The moisture content of all leaf-protein preparations was determined by drying at $102{ }^{\circ}$ for $24 \mathrm{~h}$.

\section{Nitrogen determination}

All samples for $\mathrm{N}$ determination were incinerated in sulphuric acid with $\mathrm{K}_{2} \mathrm{SO}_{4}$ : $\mathrm{CuSO}_{4}: \mathrm{SeO}_{2}(9: \mathrm{r}: 0.02)$ catalyst. A distillation method was used for samples arising from papain in vitro digestions and pepsin-pancreatin in vitro digestions; those arising from pepsin in vitro digestions and in vivo rat assays were measured on a Technicon Auto Analyser, by the method described by Technicon methodology sheet $\mathrm{N}-3 \mathrm{~b}$ (Technicon Instruments Co., Chertsey, England) by means of the Berthelot reaction described by Kaplan (1965). 


\section{Determination of total amino acids}

Samples of preparations $\mathrm{A}, \mathrm{B}$ and $\mathrm{C}$ were hydrolysed with constant boiling $\mathrm{HCl}$ under reduced pressure at $110^{\circ}$ for $18 \mathrm{~h}(\mathrm{I} \cdot 0 \mathrm{ml} \mathrm{HCl}$ to $2.0 \mathrm{mg}$ protein). After filtering through a sintered glass funnel and evaporating off the $\mathrm{HCl}$, the hydrolysate was dissolved in $0^{\circ} \mathrm{OI} \mathrm{N}-\mathrm{HCl}$ containing $\mathrm{O}^{\circ} \mathrm{r} \mu$ mole nor-leucine per $\mathrm{ml}$, and the amino acid content was determined on the Technicon Auto Analyser using the standard buffer gradient.

Results are expressed as $\mathrm{g}$ amino acid per $16 \mathrm{~g} \mathrm{~N}$. The methionine content of sample $A$ is the sum of the methionine and methionine sulphoxides found: there were only traces of sulphoxides in the hydrolysates from B and C.

\section{Microbiological assay for available amino acids}

The availability of amino acids to micro-organisms after predigestion with pepsin was determined as described by Ford (1962) with the composite standard described by Ford \& Salter (1966), Streptococcus faecalis being used to determine available lysine and Strep. zymogenes to determine available methionine, tryptophan, leucine, arginine and isoleucine.

Available lysine was also determined as described by Stott, Smith \& Rosen (1963) as modified by Stott \& Smith (1966), Tetrahymena pyriformis being used.

\section{In vivo tests of protein quality}

$B V$ and $T D$. An experiment was designed to determine the BV and TD of the four leaf-protein samples, A, B, C and D, using the general method of Mitchell (1924) as modified by Mitchell \& Carman (1926), Henry, Kon \& Watson (1937) and Buchanan (1968).

Twelve female hooded Norwegian strain rats aged 2I days, four from each of three litters were used. The basal low- $\mathrm{N}$ diet contained $0.625 \%$ egg-protein $\mathrm{N}$ and the others $\mathrm{I} \cdot 25 \%$ leaf-protein $\mathrm{N}$. Rats were offered IO-I I $\mathrm{g}$ diet per $100 \mathrm{~g}$ body-weight per day throughout each period of 8 days. Faecal N, urinary N, food consumed and changes in body-weight during the second half of each period were noted and used to calculate BV, TD and NPU for each leaf-protein sample.

The TD's of samples A, D and E were compared by the same method with six male rats aged 2r days, three from each of two litters.

Protein efficiency ratio (PER). The experiments with rats were not designed for this purpose, but PER values were calculated from the weight gain (g) per $\mathrm{g}$ protein $(\mathrm{N} \times 6.25)$ in the food consumed in the 4 test days of each period.

\section{In vitro solubility tests}

Pepsin. The solubility of leaf proteins in strong pepsin solution $(0.05 \%)$ was measured on the pepsin digests used to measure microbiologically available amino acids. It is expressed as the percentage of total substrate $\mathrm{N}$ that becomes soluble. The solubility of leaf proteins in very dilute concentrations of pepsin $(0.0002 \%)$ was also determined by the procedure of Olley \& Pirie (1966). 
Pepsin-pancreatin. Pepsin-pancreatin solubility was measured by preliminary hydrolysis with pepsin followed by pancreatin as recommended by Akeson \& Stahmann $(1964,1965)$.

Papain. The rate and extent of in vitro hydrolysis of leaf proteins by papain was measured by the method described by Buchanan \& Byers (1969).

\section{Lipid analysis}

Total lipid. Samples were extracted with three $50 \mathrm{ml}$ quantities of $2: \mathrm{I}(\mathrm{v} / \mathrm{v})$ chloroform:methanol at room temperature. The bulked lipid solutions were washed, by the method of Folch, Lees \& Stanley (1957), with $0.88 \%$ (w/v) KCl solution. Samples were evaporated to dryness for determination of total lipid.

Lipid fractionation. Extracts were prepared as for the determination of total lipid. Each was then evaporated to dryness under reduced pressure and dissolved in chloroform.

Lipid sample $\mathrm{F}$ was prepared for thin-layer chromatography (TLC) and gas-liquid chromatography (GLC) by extracting approximately $\mathrm{I} \cdot 5 \mathrm{~g}$ of leaf-protein sample $\mathrm{B}$ with $100 \mathrm{ml}$ chloroform at room temperature. The extract was washed, dried and diluted in chloroform as above.

For TLC, $5 \mathrm{ml}$ of each lipid solution were evaporated to dryness, and taken up in $0 . \mathrm{I} \mathrm{ml}$ of washed chloroform, and $I_{5} \mu \mathrm{l}$ quantities were loaded on to silica gel $\mathrm{G}$ plates $0.4 \mathrm{~mm}$ thick. To separate the phospholipids, chloroform:methanol:water:glacial acetic acid $(85: 15: 3 \cdot 6: 10)(\mathrm{v} / \mathrm{v})$ solvent (Nichols, Harris \& James, 1965) was used (Pl. I a). To separate the neutral lipids, hexane: diethyl ether:formic acid $(80: 20: 0 \cdot 4)$ (v/v) solvent (B. W. Nichols, 1967, personal communication) was used. The plates were dried and run again in the same solvent to improve the separation (P1. I $b$ ). The spots were made visible by spraying with $30 \%$ sulphuric acid and drying at about $200^{\circ}$ for about I min.

For GLC, ro $\mathrm{ml}$ of each lipid solution were methylated according to the method of Stoffel, Insull \& Ahrens (1958) by evaporating to dryness, adding $2 \mathrm{ml}$ of methanol: benzene: conc. sulphuric acid $(\mathrm{r} 50: 75: 7 \cdot 5)(\mathrm{v} / \mathrm{v})$ methylating mixture and refluxing for $90 \mathrm{~min}$. After cooling, $\mathrm{I} \mathrm{ml}$ light petroleum (b.p. $40^{\circ}-60^{\circ}$ ) and $\mathrm{I} 5 \mathrm{ml}$ water were added and the whole was shaken; when the emulsion had separated, the lower aqueous phase was discarded. After two further washes with water the mixture was evaporated to dryness under reduced pressure, taken up in $2 \mathrm{ml}$ of methanol and filtered through cotton wool. The filtrate was evaporated to dryness, dissolved in $0.2 \mathrm{ml}$ methanol and examined on a Pye I04, Model 64 chromatograph with dual-heated flame ionization detectors using a polyethylene glycol adipate column with argon carrier gas. The initial temperature was $70^{\circ}$ and increased at $8^{\circ}$ per min to a final temperature of $190^{\circ}$.

Esters were identified by comparing relative retention times with those of standard esters. The amount of each component was determined from the area under its peak, taken as peak height multiplied by peak width at half height. Detector response was determined from a mixture of standard esters. 


\section{RESULTS}

Table I shows the composition of samples A, B, C and D.

\section{Determination of total amino acids}

The comparison in Table 2 of amino acid contents of the leaf-protein samples A, B and C with the FAO (I957) Provisional Pattern, shows that the essential amino acids are present in adequate quantities and there is little variation between samples although $\mathrm{B}$ and $\mathrm{C}$ contained less lysine than the fresh sample, $\mathrm{A}$.

\section{Microbiological assay for available amino acids}

Table 3 shows the amounts of available tryptophan, leucine, isoleucine, arginine and methionine determined with Strep. zymogenes and available lysine determined with Strep. faecalis. The method sometimes gives inconsistent results and in these determinations the availability of lysine and isoleucine was inconsistent at different protein

Table I. Composition of the wheat leaf-protein samples used to compare various methods of estimating nutritive value

\begin{tabular}{|c|c|c|c|}
\hline Leaf-protein preparation & $\begin{array}{l}\text { Moisture } \\
\quad(\%)\end{array}$ & $\begin{array}{l}\text { Nitrogen } \\
\text { (\% of dry } \\
\text { matter) }\end{array}$ & $\begin{array}{l}\text { Lipid } \\
\text { (\% of dry } \\
\text { matter) }\end{array}$ \\
\hline Freshly freeze-dried & $2 \cdot 3$ & $10 \cdot 5$ & $29^{\circ} 0$ \\
\hline $\begin{array}{l}\text { Heated } \\
\text { Extracted with chloroform }\end{array}$ & $\begin{array}{l}8 \cdot 0 \\
5 \cdot 4\end{array}$ & $\begin{array}{l}10.5 \\
13.4\end{array}$ & $\begin{array}{l}25 \cdot 6 \\
10 \cdot 2\end{array}$ \\
\hline $\begin{array}{l}\text { Fresh after acid } \\
\text { solvent extraction }\end{array}$ & $6 \cdot 3$ & $14 \cdot 4$ & 0.0 \\
\hline
\end{tabular}

Table 2. Amino acid composition of three wheat leaf-protein samples, $A, B$ and $C$ (see p. 534) compared to the FAO Provisional Pattern (g/16 g N)

\begin{tabular}{|c|c|c|c|c|}
\hline Amino acid & A & B & $\mathrm{C}$ & $\begin{array}{c}\text { FAO (1957) } \\
\text { Provisional } \\
\text { Pattern }\end{array}$ \\
\hline Aspartic & 10.5 & 10.4 & 10.3 & 一 \\
\hline Threonine & $5 \cdot 5$ & $5 \cdot 5$ & $5 \cdot 5$ & $2 \cdot 8$ \\
\hline Serine & $5 \cdot I$ & $5 \cdot I$ & 5.0 & - \\
\hline Glutamic & $12 \cdot 2$ & $12 \cdot 4$ & $12 \cdot 2$ & - \\
\hline Proline & $5 \cdot 3$ & $5 \cdot 5$ & 5.4 & - \\
\hline Glycine & $6 \cdot 1$ & $6 \cdot 2$ & $6 \cdot 1$ & - \\
\hline Alanine & $7 \cdot 5$ & $7 \cdot 6$ & $7 \cdot 8$ & - \\
\hline Valine & $6 \cdot 9$ & $6 \cdot 8$ & $7 \cdot 0$ & $4 \cdot 2$ \\
\hline Cystine & I.7 & $1 \cdot 7$ & I.9 & $2 \cdot 0$ \\
\hline Methionine & $2 \cdot 5$ & $2 \cdot 7$ & $2 \cdot 5$ & $2 \cdot 2$ \\
\hline Isoleucine & $5 \cdot 3$ & $5 \cdot 3$ & $5 \cdot 4$ & $4 \cdot 2$ \\
\hline Leucine & $9 \cdot 9$ & $9^{-9}$ & $9 \cdot 9$ & $4 \cdot 8$ \\
\hline Tyrosine & 47 & $5^{\circ} \mathrm{O}$ & $5^{\circ} \circ$ & $2 \cdot 8$ \\
\hline Phenylalanine & $6 \cdot 6$ & $6 \cdot 7$ & 6.7 & $2 \cdot 8$ \\
\hline Ammonia & $I \cdot 5$ & $I \cdot 6$ & $\mathrm{I} \cdot 5$ & 一 \\
\hline Lysine & $7 \cdot 2$ & $6 \cdot 7$ & $6 \cdot 7$ & $4 \cdot 2$ \\
\hline Tryptophan & $*$ & $*$ & $*$ & $1 \cdot 4$ \\
\hline Histidine & $2 \cdot 5$ & $2 \cdot 4$ & 2.5 & - \\
\hline Arginine & $7 \cdot 3$ & $7 \cdot 1$ & $7 \cdot 3$ & - \\
\hline
\end{tabular}

* Not determined, but 'available' tryptophan values ranged from I.6 to $2 \cdot \mathrm{I} g / \mathrm{I} 6 \mathrm{~g} \mathrm{~N}$ (see Table 3 ). 
concentrations. However, there seemed to be a general pattern, common to all the amino acids, that in $\mathrm{B}$ they were $10-20 \%$ less available than in $\mathrm{A}$; in $\mathrm{C}$ they were equally available as, or slightly less available than, in $\mathrm{B}$; in D they were about $5 \%$ more available than in $\mathrm{A}$.

Microbiological assay of available lysine determined with Tetrahymena pyriformis gave smaller values for $\mathrm{B}, \mathrm{C}$ and $\mathrm{D}$ than for $\mathrm{A}$ (Table 3).

Table 3. Microbiologically available amino acids in four leaf-protein preparations $A-D$ (see p. 534) (g/16 g N)

\begin{tabular}{|c|c|c|c|c|c|}
\hline Amino acid & A & B & $\mathrm{C}$ & $\mathrm{D}$ & $\begin{array}{l}\text { Total * } \\
\text { amino acids } \\
\text { in A }\end{array}$ \\
\hline \multicolumn{6}{|l|}{ Streptococcus zymogenes } \\
\hline Methionine & $2 \cdot 2$ & $2 \cdot 0$ & $\mathbf{r} \cdot 9$ & $2 \cdot 4$ & $(2 \cdot 5)$ \\
\hline Tryptophan & $2 \cdot 0$ & $\mathrm{I} \cdot 7$ & $\mathrm{I} \cdot 6$ & $2 \cdot i$ & - \\
\hline Leucine & $7 \cdot 9$ & $6 \cdot 5$ & $6 \cdot 5$ & $8 \cdot \mathrm{I}$ & $(9 \cdot 9)$ \\
\hline Arginine & $7 \cdot 4$ & $6 \cdot I$ & 5.8 & $7 \cdot 6$ & $(7 \cdot 3)$ \\
\hline Isoleucine & $5 \cdot 5$ & $5 \cdot 0$ & 4.7 & $5 \cdot 6$ & $(5 \cdot 3)$ \\
\hline \multicolumn{6}{|l|}{ Strep. faecalis } \\
\hline Lysine & $5 \cdot 0$ & $4 \cdot 0$ & 3.4 & $5 \cdot 3$ & $(7 \cdot 2)$ \\
\hline \multicolumn{6}{|c|}{ Tetrahymena pyriformis } \\
\hline Lysine & $2 \cdot 7$ & $I \cdot O$ & $\mathbf{I} \cdot \mathbf{O}$ & $I \cdot I$ & - \\
\hline
\end{tabular}

* Determined by chemical amino acid analysis of an acid-hydrolysate.

\section{In vivo tests of protein quality}

A summary and statistical analysis of the results are given in Table 4. The BV of each of samples A, C and D was 85 and that of $B$ was 80 . Although $B$ was lower than $A, C$ and $D$, it was not significantly less than $A$ or $C$ or $D$.

TD values showed no significant difference between $A$ and $C$ but for $B$ the value was significantly less than for $\mathrm{A}$ and $\mathrm{C}$. The value for $\mathrm{D}$ was significantly less than that for B.

The trends and significance of the NPU results were the same as those for TD. PER values also showed this same trend with $\mathrm{D}<\mathrm{B}<\mathrm{A}$ and $\mathrm{C}$.

A second experiment showed similar TD and PER values for $A$ and $D$ and showed that the poor TD and PER of $\mathrm{D}$ could be overcome by adequate washing with water and adjustment of $\mathrm{pH}$ before drying (E).

\section{Papain in vitro solubility}

Solubilization of LPC samples A, B, C and D with papain (Table 5) showed that moist heating greatly decreased the rate and extent of solubilization-from 76 to $44 \%$ after $48 \mathrm{~h}$ incubation. However, chloroform extraction of the heated sample (C) almost restored the original rate and extent of solubilization- $72 \%$ after $48 \mathrm{~h}$. Extraction with an acidified solvent (D) decreased the extent of papain solubilization$20 \%$ after $48 \mathrm{~h}$-although initially solubilization was reasonably fast, with $6 \%$ solubilized after $\mathrm{I} h$.

Table 5 also shows the effect of several treatments on the solubility of sample D by 
papain. A dry sample fine enough to pass through a roo-mesh screen was compared with another dry sample too coarse to pass a 60-mesh screen but fine enough to pass a $40-$ mesh screen. There was very little difference in the rate or extent of solubilization. Both of the presoaked samples were solubilized much more than the two dry samples of D.

A similar experiment showed no change in the rate or extent of digestion of heated leaf protein, B, after grinding finely enough to pass a Ioo mesh screen.

Table 4. True digestibility (TD), biological value $(B V)$, net protein utilization $(N P U)$ and protein efficiency ratio (PER) of leaf-protein preparations fed to rats

(PER was measured as weight gain $(\mathrm{g})$ per $\mathrm{g}$ protein $(\mathrm{N} \times 6 \cdot 25)$ eaten during 4 days)

\begin{tabular}{|c|c|c|c|c|c|c|}
\hline $\begin{array}{l}\text { Leaf-protein } \\
\text { preparation }\end{array}$ & TD* & $\mathrm{BV}^{*}$ & NPU & $\begin{array}{c}\text { Mean } \\
\text { weight } \\
\text { gain } \\
\text { (g) }\end{array}$ & $\begin{array}{c}\text { Mean } \\
\text { protein } \\
\text { eaten } \\
\text { (g) }\end{array}$ & PER \\
\hline \multicolumn{7}{|c|}{ Expt I } \\
\hline A & $8 r \cdot 6 \pm r \cdot 54$ & $84 \cdot 8 \pm 2 \cdot 17$ & $69 \cdot 2$ & $+2 \cdot 3$ & $x \cdot 40$ & $+I \cdot 6$ \\
\hline B & $72 \cdot 1 \pm I \cdot 48$ & $80 \cdot 1 \pm 2.07$ & $57 \cdot 7$ & $+1 \cdot 2$ & - $\cdot 38$ & +0.9 \\
\hline C & $80 \cdot 4 \pm \mathrm{I} \cdot 54$ & $85 \cdot 3 \pm 1 \cdot 98$ & $68 \cdot 7$ & +2.5 & $1 \cdot 44$ & $+1 \cdot 7$ \\
\hline D & $53 \cdot 8 \pm x \cdot 70$ & $84 \cdot 8 \pm 2 \cdot 29$ & $45^{\circ} 6$ & -0.8 & $1 \cdot 24$ & -0.6 \\
\hline \multicolumn{7}{|c|}{ Expt 2} \\
\hline A & $81 \cdot 2 \pm 2 \cdot 77$ & - & - & $+1 \cdot 7$ & I.53 & $+\mathrm{I} \cdot \mathbf{I}$ \\
\hline D & $5^{6 \cdot 2} \pm 3 \cdot 10$ & - & - & $+o \cdot r$ & $x \cdot 53$ & $+0 . \mathrm{I}$ \\
\hline $\mathrm{E}$ & $90 \cdot 6 \pm 2 \cdot 77$ & - & - & $+5 \cdot 3$ & 1.67 & +3.2 \\
\hline
\end{tabular}

Expt I

Statistical significance

TD $\mathrm{D}<\mathrm{B}<\mathrm{A}$ and $\mathrm{C}$. This was significant at the $0 . \mathrm{I} \%$ leve! Bv Differences not significant

Expt 2

TD D $<\mathrm{A}<\mathrm{E}$. This was significant at the $0 . \mathrm{I} \%$ level

* Mean values with their standard errors.

Table 5. Rate of solubilization with papain of several leaf-protein preparations

\begin{tabular}{|c|c|c|c|c|c|c|c|}
\hline \multirow[b]{2}{*}{ Leaf-protein preparation } & \multicolumn{7}{|c|}{ Solubility in papain $(\%)$} \\
\hline & I h & $2 \mathrm{~h}$ & $4 \mathrm{~h}$ & $8 \mathrm{~h}$ & $15 \mathrm{~h}$ & $24 \mathrm{~h}$ & $48 \mathrm{~h}$ \\
\hline A Freshly freeze-dried & 20 & 38 & 53 & 63 & 69 & 72 & 76 \\
\hline B Heated & 2 & 6 & 10 & 17 & 24 & $3 I$ & 44 \\
\hline $\begin{array}{l}\text { C Extracted with chloroform } \\
\text { after heating }\end{array}$ & II & 26 & 43 & 57 & 64 & 69 & 72 \\
\hline $\begin{array}{l}\text { D Fresh, after acid-solvent } \\
\text { extraction }\end{array}$ & 6 & 7 & 8 & I I & 12 & I6 & 20 \\
\hline Fractions of D: & & & & & & & \\
\hline Fine, dry & 3 & 4 & 6 & 9 & 12 & 14 & 19 \\
\hline Coarse, dry & 6 & 7 & 8 & 7 & 9 & I I & $x 6$ \\
\hline Fine, presoaked & 9 & I6 & 25 & 34 & 38 & 47 & 57 \\
\hline Coarse, presoaked & IO & 17 & 23 & $3 I$ & 33 & 37 & 54 \\
\hline
\end{tabular}




\section{Pepsin solubility}

Table 6 gives the degree of solubilization of the preparations with strong $(0.05 \%)$ pepsin solution, used in the predigestion for the available amino acids determinations. $B$ was solubilized less than $A$, whereas $C$ and $D$ were solubilized more than $A$.

Table 6 also shows that with very dilute $(0.0002 \%)$ concentrations of pepsin, samples $\mathrm{B}, \mathrm{C}$ and $\mathrm{D}$ were solubilized more slowly than the untreated sample A.

Table 6. Summary of determinations of nutritive value of samples of leaf-protein $A-E$ (see p. 534)

Biological value
True digestibility : Expt I
Expt 2
Net protein utilization
Protein efficiency ratio : Expt I
Expt 2
Papain digestibility: I $5 \mathrm{~h}$
$20 \mathrm{~h}$
$48 \mathrm{~h}$
Pepsin-pancreatin digestibility
Solubility in $0.62 \% \mathrm{HCl}$
Solubility in $0.62 \% \mathrm{HCl}+0.0002 \%$
pepsin
Corrected $0.0002 \%$ pepsin digestibility
0.05\% pepsin digestibility
Streptococcus faecalis available lysine
Strep. zymogenes available methionine
Tetrahymena pyriformis available lysine

$\begin{array}{ccccc}\text { A } & \text { B } & \text { C } & \text { D } & \text { E } \\ 85 & 80 & 85 & 85 & - \\ 82 & 72 & 80 & 54 & - \\ 81 & - & - & 56 & 9 \text { I } \\ 69 & 58 & 69 & 46 & - \\ \text { I.6 } & 0 \cdot 9 & \text { I.7 } & -0 \cdot 6 & - \\ \text { I.I } & - & - & 0 \cdot 1 & 3 \cdot 2 \\ 69 & 24 & 64 & 12 & - \\ 71 & - & - & 14 & 76 \\ 76 & 44 & 72 & 20 & - \\ 69 & 43 & 55 & 24 & - \\ 9 & 9 & 7 & 11 & - \\ 30 & 16 & 16 & 20 & - \\ & & & & \\ 23 & 8 & 10 & 10 & - \\ 73 & 67 & 81 & 79 & - \\ 5 \cdot 0 & 4 \cdot 0 & 3 \cdot 4 & 5 \cdot 3 & - \\ 2 \cdot 2 & 2 \cdot 0 & 1 \cdot 9 & 2 \cdot 4 & - \\ 2 \cdot 7 & 1 \cdot 0 & \text { I.0 } & 1 \cdot 1 & -\end{array}$

\section{Pepsin-pancreatin solubility}

Table 6 shows the extent of solubilization by pepsin followed by pancreatin (Akeson \& Stahmann, I964). Moist heating decreased the percentage solubility from $69 \%$ (A) to $43 \%$ (B) but after extracting the heated material with chloroform the percentage solubility increased slightly to $55 \%$ (C). The protein extracted with acidified chloroform-methanol (D) was only $24 \%$ solubilized.

There was little difference between the TLCs of phospholipids (P1. I $a$ ) and neutral lipids (Pl. I $b$ ) extracted from fresh (A) and heated (B) leaf protein. The chloroform extract $(F)$ from heated material contained most of the neutral lipid but also a range of other identifiable classes of lipid. Extraction with chloroform removed about twothirds of the lipid, including almost all the sterol esters, triglycerides, free fatty acids, I:3- and I :2-diglycerides, free sterols and monogalactosyl diglycerides, but less than two-thirds of the sterol glycosides, phosphatidyl ethanolamine, digalactosyl diglyceride and sulpholipids.

The GLCs of the methyl esters of these lipids (Table 7) showed only one major difference between the fresh (A) and heated (B) samples-a decrease in the amount of linolenic (18:3) acid extractable with $2: 1$ (v/v) chloroform:methanol after heating. Extracting the heated material with chloroform at room temperature removed nearly 
all of the more-polar fatty acids containing less than 16 carbon atoms, but less than two-thirds of the fatty acids containing 16 to 18 carbon atoms, including the saturated palmitic (I6:0) and stearic (I8:0) and the unsaturated oleic (I8:I), linoleic (18:2) and linolenic (18:3) acids. In Table 7 the values obtained are compared with those published by Lima, Richardson \& Stahmann (1965).

Table 7. Distribution of fatty acids in lipids extracted from wheat leaf-protein samples $A, B$ and $C$, compared with values given by Lima, Richardson $\mathbb{F}^{\circ}$ Stahmann (1965)

\begin{tabular}{|c|c|c|c|c|c|c|c|c|c|}
\hline \multirow{2}{*}{$\begin{array}{l}\text { Methyl } \\
\text { ester * }\end{array}$} & \multicolumn{5}{|c|}{$\begin{array}{c}\text { Composition of fatty acid esters } \\
(\% \text { of total })\end{array}$} & \multicolumn{4}{|c|}{$\begin{array}{c}\text { mg fatty acid esters per g origin } \\
\text { protein }(\mathrm{N} \times 6 \cdot 25) \dagger\end{array}$} \\
\hline & A & B & $\mathrm{C}$ & $\mathbf{F}$ & Lima et al. & $\mathbf{A}$ & B & C & $F$ \\
\hline $18: 3$ & $52 \cdot 5$ & $47^{\circ} 9$ & $58 \cdot 9$ & $5 \mathrm{I} \cdot 5$ & $53^{\circ} 7$ & $23 \cdot 1$ & 18.6 & $7 \cdot 0$ & I 3.8 \\
\hline $18: 2$ & 10.4 & 10.8 & $I I \cdot 2$ & II 2 & 13.8 & $4 \cdot 6$ & $4 \cdot 2$ & I.3 & $3 \cdot 0$ \\
\hline $18: 1$ & $2 \cdot 5$ & $3 \cdot 7$ & $3 \cdot 3$ & $2 \cdot 8$ & $5 \cdot 9$ & $I \cdot I$ & $I \cdot 4$ & 0.4 & 0.8 \\
\hline $18: 0$ & 0.8 & $1 \cdot 2$ & $x \cdot 6$ & 0.9 & $2 \cdot 5$ & 0.4 & 0.5 & 0.2 & $0 \cdot 3$ \\
\hline $16: 0$ & 15.5 & $18 \cdot 4$ & $22 \cdot 7$ & $16 \cdot 1$ & $15 \cdot 9$ & $6 \cdot 8$ & $7 \cdot 1$ & $2 \cdot 7$ & $4 \cdot 3$ \\
\hline$I_{4}: 0$ & $x \cdot 6$ & $2 \cdot 3$ & 0.3 & $I \cdot 8$ & 0.5 & 0.7 & 0.9 & 0.0 & 0.5 \\
\hline $12: 0$ & 0.2 & 0.4 & 0.0 & 0.4 & 0.2 & 0.1 & 0.1 & 0.0 & 0.1 \\
\hline Others & $16 \cdot 6$ & $15 \cdot 3$ & $2 \cdot 0$ & $15 \cdot 3$ & $6 \cdot 5$ & $7 \cdot 3$ & $5 \cdot 9$ & 0.2 & $4 \cdot I$ \\
\hline Total & IOO'I & 100.0 & $100 \cdot 0$ & 100.0 & $99 \cdot 0$ & $44^{\prime} I$ & $3^{8 \cdot 7}$ & I I 8 & $26 \cdot 9$ \\
\hline
\end{tabular}

A, chloroform:methanol $(2: 1)(\mathrm{v} / \mathrm{v})$ extract of fresh leaf protein; B, chloroform:methanol $(2: \mathrm{I})(\mathrm{v} / \mathrm{v})$ extract of heated leaf protein; C, chloroform: methanol $(2: \mathrm{I})$ ( $\mathrm{v} / \mathrm{v})$ extract of heated leaf protein after chloroform extraction; F, chloroform extract of heated leaf protein.

* No of carbons: no of double bonds.

† Assuming $3 \%$ of original $\mathbf{N}$ lost during chloroform extraction.

\section{DISCUSSION}

One object of this work was to compare various in vitro methods with in vivo methods of estimating the nutritive value of leaf proteins, especially their sensitivity in detecting losses caused by heating and extraction with acidified solvents.

The BV, TD, NPU and PER for leaf proteins fed as the sole source of nitrogen to young rats are not necessarily satisfactory estimates of the nutritive value of such leaf proteins for children, adults or other non-ruminant animals. However it is reasonable to assume that they are a better index of nutritive value for man than any of the in vitro methods, yet enzyme solubilization tests in vitro are widely used as rapid methods for estimating protein quality. This study shows some of their limitations, based on the assumption that the rat tests give the correct result.

\section{Effect of moist heating}

The summary of determinations of nutritive value (Table 6) shows that all these methods predict some loss in nutritive value after heating a leaf-protein sample containing $8 \%$ moisture for $5 \mathrm{~h}$ at $105^{\circ}$ (A v. B). However, it is notable that the effect of heating was overestimated by all the in vitro methods, except solubility using concentrated pepsin $(0.05 \%)$.

The solubility of B was much less than that of A with weak $(0.0002 \%)$ pepsin but 
not so much less with strong $(0.05 \%)$ pepsin. Differences in solubility were also greater with papain solubilization after IO- $15 \mathrm{~h}$ than after $48 \mathrm{~h}$. Hence, although heating had a considerable effect on solubilization rates, it did not necessarily much affect the ultimate extent of solubilization.

The total amino acid composition (Table 2) and microbiological tests for available amino acids (Table 3) suggest that methionine or total sulphur-containing amino acids were limiting for the fresh leaf protein (A). However, during heating more available lysine seems to be lost than available methionine, so that after heating lysine may be limiting and this may be the cause of the decrease in Bv from 85 to $80 \%$.

The decrease in the amount of linolenic (I8:3) and linoleic acids (18:2) extractable after heating, without any corresponding increase in other less saturated fatty acids, is evidence that the linolenic and linoleic acids have formed complexes with other compounds in the leaf protein. The other possibility, that these unsaturated acids have been oxidized by atmospheric oxygen, is unlikely because the losses of solubility in papain after moist heating depend mainly on moisture content and occur in an atmosphere of $\mathrm{N}_{2}$ just as readily as in air (Buchanan, 1969). Mere grinding of heated leaf protein does not affect the rate of solubilization by papain. Thus it seems that the loss of solubility is not caused by surface action spreading a film of oxidized fat across the protein, as described by Geisler \& Contreras (1967) and Olley \& Pirie (1966) for fish meals. The formation of complexes with unsaturated lipids is probably related to the losses in TD and enzyme solubility. This is supported by the following effects of extraction with mild solvents after heating.

\section{Effect of extraction with chloroform after heating}

The loss in nutritive value on heating leaf protein can be largely reversed by mild solvent extraction. This applies to all the in vivo criteria used, i.e. BV, TD, NPU and PER.

The same pattern is not maintained, however, in the in vitro tests; solubility in weak pepsin is virtually unaffected by chloroform extraction although this treatment substantially increases solubility in strong pepsin (Table 6). Solubility of heated protein in pepsin-pancreatin is greater after extraction with chloroform but the increase is only about half the decrease caused by heating the protein. Solubility of heated protein in papain is also greater after extraction with chloroform and in this instance the increase is almost as great as the decrease caused by heating the protein. Thus papain solubilization reflects the same trends as in vivo TD.

There are differences between the lipids remaining and those extracted by chloroform after heating. The similarity in the rates of solubilization by papain after extraction with chloroform or $2: \mathrm{x}$ chloroform:methanol shows that the lipid remaining after extraction with chloroform (approximately one-third of that which can be extracted by $2:$ I chloroform:methanol) did not influence the rate or extent of solubilization with papain. However, it is not clear whether the chloroform removed sufficient lipid to prevent its acting as a physical barrier between the enzyme and protein or was effective because it removed nearly all the neutral lipids and the fatty acids containing less than I6 carbon atoms.

The removal of these neutral lipids and lower fatty acids had a negligible effect on 
the rate of solubilization by dilute pepsin (Table 6). A sufficient physical barrier of lipid may have remained, but probably the more polar-lipids or the higher unsaturated fatty acids, or both, had formed complexes that inhibited pepsin proteolysis. The fact that more concentrated pepsin ('Table 6) gives a greater degree of solubilization after lipid extraction suggests that pepsin can eventually break these lipid-protein linkages.

\section{Effect of acid-solvent extraction}

Although extraction with $2: \mathrm{I}(\mathrm{v} / \mathrm{v})$ chloroform:methanol $+\mathrm{I} \% \mathrm{HCl}$ (sample D) did not change the BV of the leaf protein, it decreased TD, and consequently NPU and PER. This was reflected in a decrease in solubility in papain, pepsin-pancreatin and weak $(0 \cdot 0002 \%)$ pepsin. However, the availability of all amino acids to streptococci after predigestion with pepsin was increased because solubility of the protein in the pepsin was increased (Table 6).

In sample $\mathrm{D}$ the dry leaf protein was hard, horny and difficult to wet, probably partly because of acid absorbed from the acidified solvent. A similar loss of digestibility was noted by Buchanan (1969) in a sample extracted with boiling 2 : I chloroform: methanol $+\mathrm{I} \% \mathrm{HCl}$ in a Soxhlet and in one extracted for $4 \mathrm{~h}$ with boiling methanol in a Soxhlet. In each the horny brittle texture of the dry protein was probably the direct cause of the loss in digestibility and solubility in enzymes. Where residual acid was present it probably influenced the texture, although in $\mathrm{D}$ it had very little effect on the $\mathrm{pH}$ of protein suspensions in water or weak buffers. As shown in Table 5, presoaking, which swells the protein, increased the rate of papain solubilization, whereas differences in particle size had little effect, presumably because the small and large particles had the same basic texture. The texture of dry leaf-protein preparations is affected by the procedure used during freeze-drying; this too may affect digestibility. Long experience at Rothamsted shows that the greater the water content before freezedrying, the softer and more powdery the dry leaf protein.

Dry preparations are very convenient, both in research and in practical use, but whenever a protein has less nutritive value than its amino acid composition would suggest, an attempt should be made to test it in the undried state.

When the protein was extracted with acid solvent, washed in several volumes of water, and neutralized to $\mathrm{pH} 6$ before drying (sample $\mathrm{E}$ ), the in vitro papain solubility, TD and PER (Table 6) increased above those of the original fresh whole leaf protein. The TD of sample E ( $9 \mathrm{r} \%$ ) was greater than has been achieved for any other leaf-protein preparation. If this could be repeated on a large scale it would significantly improve the nutritive value of leaf proteins and might make a solvent extraction process worth while.

Similar variations in texture could have contributed to an unexpected growthdepressant action found by Carpenter, Lea \& Parr (1963) in herring meal after extraction with chloroform-methanol solvent, or to toxicity found by Morrison, Sabry \& Middleton (1962) in fish flour after extraction with chloroform. They found that subsequent extraction with ether removed the growth-depressant or toxic factor. The results of my experiments with LPC suggest that the ether may have modified the texture of the fish protein to increase digestibility or release bound chloroform, or both. 


\section{Evaluation of in vitro tests}

The samples used in this work had similar Bvs but their digestibilities differed. The papain solubilization procedure showed the best correlation with TD. The pepsinpancreatin solubility was almost as good though it underestimated the recovery in digestibility after chloroform extraction of heat-damaged protein. However, if this deficiency can be overcome, the pepsin-pancreatin index, with amino acid analysis of the solubilized protein, seems to be a promising in vitro method of estimating the nutritive value of leaf proteins.

Pepsin was used at $0.0002 \%$ and $0.05 \%$ concentrations; neither offers a satisfactory method of estimating the digestibility of proteins such as leaf proteins when the lipid content can so influence the solubility in vivo. Predigestion with $0.05 \%$ pepsin is not a suitable method of preparing leaf-protein concentrates for microbiological assay of available amino acids. The general method could possibly be adapted for use after papain or pepsin-pancreatin predigestion.

The determination of available lysine with $T$. pyriformis involves no enzyme predigestion but includes a preliminary solvent extraction, which excludes the possibility of detecting the type of heat damage described here (B compared with A). The comparison of $A$ and $C$ suggests that the method also overestimates the losses caused by modification of the protein after heating.

The author is grateful to $\mathrm{Mr} \mathrm{N}$. W. Pirie, FRS, for guidance throughout the course of this work and to Marjorie Byers for the amino acid analyses. Some of this work was done at the National Institute for Research in Dairying and thanks are due to Drs M. E. Coates and J. W. G. Porter and Miss Mary 'Tyler for advice and assistance with the rat assays, Dr J. E. Ford and Mr K. J. Scott for assistance with the microbiological assays and Mr J. D. Edwards-Webb for the GLC and TLC analyses.

This work was part of the requirement for a $\mathrm{PhD}$ degree at London University. Financial support was received from an Australian Commonwealth Scientific and Industrial Research Organization Traineeship.

\section{REFERENCES}

Akeson, W. R. \& Stahmann, M. A. (1964). F. Nutr. 83, 257.

Akeson, W. R. \& Stahmann, M. A. (1965). F. agric. Fd Chem. 13, 145.

Buchanan, R. A. (I968). Changes in leaf protein preparations during storage. PhD Thesis, London University.

Buchanan, R. A. (1969). F. Sci. Fd Agric. (In the Press.)

Buchanan, R. A. \& Byers, M. (1969). F. Sci. Fd Agric. (In the Press.)

Carpenter, K. J., Lea, C. H. \& Parr, L. J. (1963). Br. F. Nutr. 17, I 5 1.

Duckworth, J., Hepburn, W. R. \& Woodham, A. A. (196r). F. Sci. Fd Agric. 12, 16.

Duckworth, J. \& Woodham, A. A. (196r). F. Sci. Fd Agric. 12, 5.

Ellinger, G. M. (1954). Wld's Poult. Congr. x. Edinburgh Part 2, p. 128.

FAO (1957). F.A.O. nutr. Stud. no. I6.

Folch, J., Lees, M. \& Stanley, G. H. S. (I957). F. biol. Chem. 226, 497.

Ford, J. E. (1962). Br. F. Nutr. 16, 409.

Ford, J. E. \& Salter, D. N. (1966). Br. F. Nutr. 20, 843.

Geisler, H. W. \& Contreras, E. (1967). Fshg News int. 6, 38.

Gerloff, E. D., Lima, I. H. \& Stahmann, M. A. (1965). F. agric. Fd Chem. 13, 139. 
British fournal of Nutrition, Vol. 23, No. 3

Plate I

A

B

C

$\mathrm{F}$

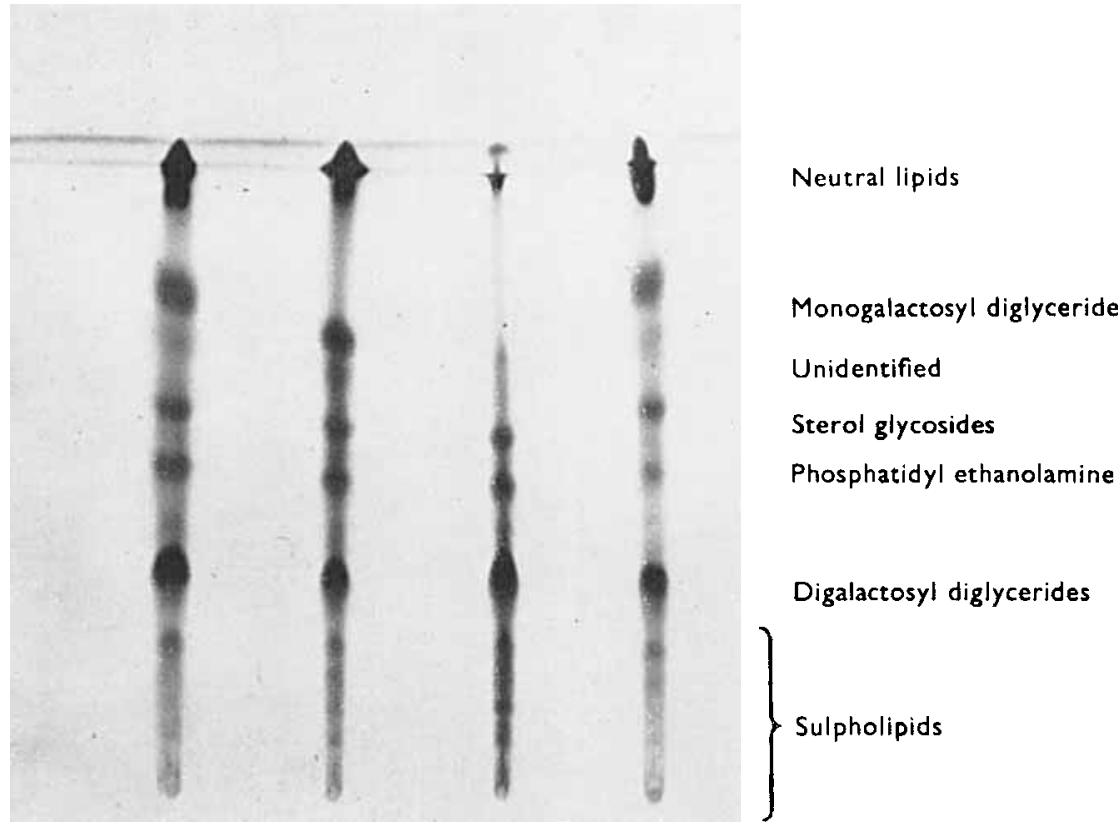

(a)

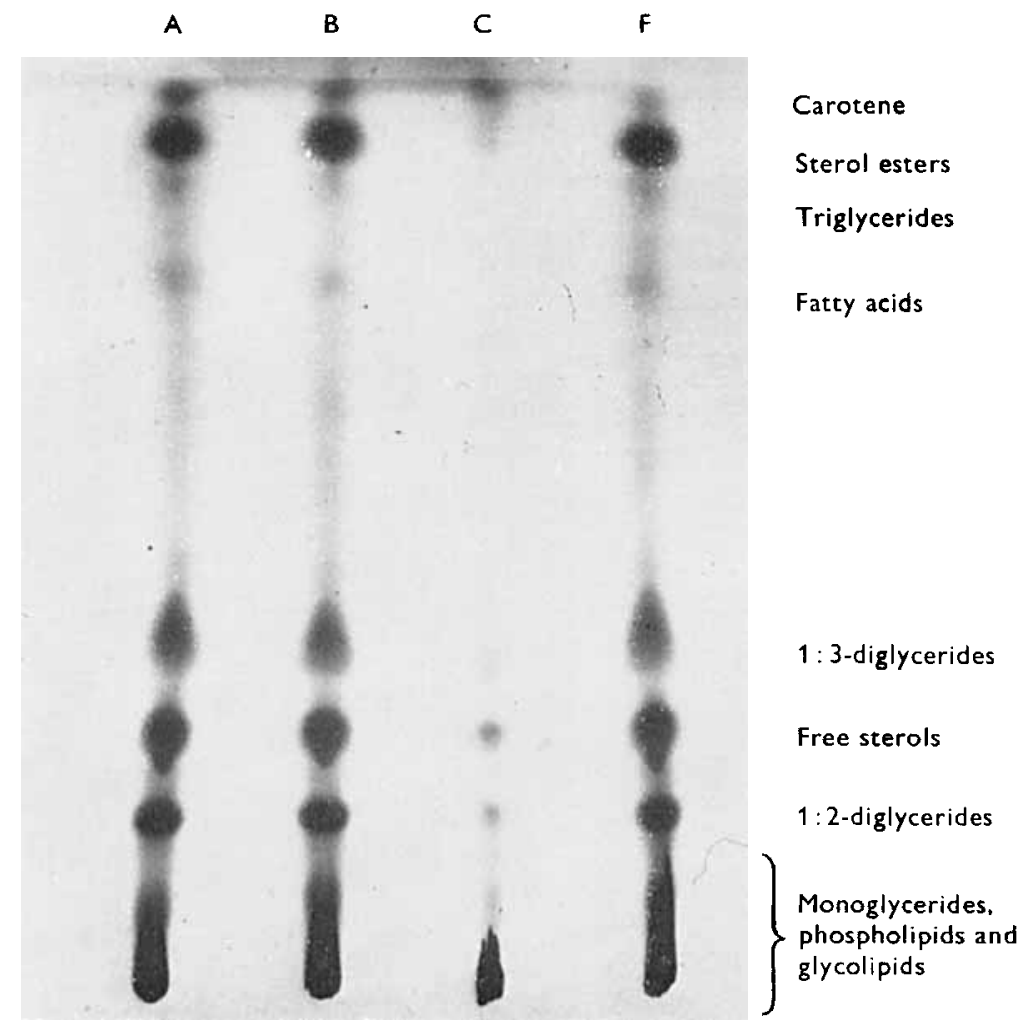

(b) 
Henry, K. M. (1959). Rep. natn. Inst. Res, Dairy. p. 97.

Henry, K. M. \& Ford, J. E. (1965). F. Sci. Fd Agric. 16, 425.

Henry, K. M., Kon, S. K. \& Watson, M. B. (1937). In Milk and Nutrition, Part I, p. 37. Reading: National Institute for Research in Dairying.

Kaplan, A. (1965). Stand. Meth. clin. Chem. 5, 245.

Lima, I. H., Richardson, T. \& Stahmann, M. A. (1965). F. agric. Fd Chem. 13, 143.

Mitchell, H. H. (1924). F. biol. Chem. 58, 873 .

Mitchell, H. H. \& Carman, G. G. (1926). F. biol. Chem. 68, 183.

Morrison, A. B., Sabry, Z. I. \& Middleton, E. J. (1962). Y. Nutr. 77, 97.

Morrison, J. E. \& Pirie, N. W. (1961). F. Sci, Fd Agric. 12, I.

Nichols, B. W., Harris, R. V. \& James, A. T. (1965). Biochem. biophys. Res. Commun. 20, 256.

Olley, J. \& Pirie, R. (1966). Fshg News int. 5, (12), 27.

Pleshkov, B. P. \& Fowden, L. (I959). Nature, Lond. 183, 1445.

Stoffel, W., Insull, W. Jr \& Ahrens, E. H. Jr (I958). Proc. Soc. exp. Biol. Med. 99, 238.

Stott, J. A. \& Smith, H. (1966). Br. F. Nutr. 20, 663.

Stott, J. A., Smith, H. \& Rosen, G. D. (1963). Br. F. Nutr. r9, 227.

Valli Devi, A., Rao, N. A. N. \& Vijayaraghavan, P. K. (1965). F. Sci. Fd Agric. I6, I 16.

Waterlow, J. C. (1962). Br. F. Nutr. r6, 53 I.

\section{EXPLANATION OF PLATE}

Separation by thin-layer chromatography on silica gel of phospholipids and neutral lipids of leaf protein, (A) fresh, (B) heated and (C) heated after chloroform extraction, and of (F) chloroform extract of heated protein. (a) Separation of phospholipids, identifying the major components. (b) Separation of neutral lipids, showing probable identity of compounds separated. 